DOI 10.37882/2223-2982.2020.08.31

\title{
ФУНКЦИОНАЛЬНОЕ ИССЛЕДОВАНИЕ ФРАЗЕОЛОГИЧЕСКИХ ЕДИНИЦ РУССКОГО И КИТАЙСКОГО ЯЗЫКОВ В КОНТЕКСТЕ ПОСТРОЕНИЯ РУССКО-КИТАЙСКОГО СЛОВАРЯ 1
}

\section{FUNCTIONAL RESEARCH OF THE PHRASEOLOGICAL UNITS OF THE RUSSIAN AND CHINESE LANGUAGES IN THE CONTEXT OF THE CONSTRUCTION OF THE RUSSIAN-CHINESE DICTIONARY}

\section{Song Shufeng}

Summary: The article is devoted to reflecting the importance of studying phraseological units of Russia and China. The relevance of the work is due to the importance of establishing intercultural interaction, as well as the desire to understand the speaker of another language. The main task of the study is an attempt to systematize information about compiling a single dictionary. The author proposes to create a Russian-Chinese dictionary of phraseological units, with the help of which it would be easier to understand cultural differences between countries. At the end of the work, the author comes to the conclusion that the study of phraseological expressions of the two countries allows you to understand the difference between the two cultures, absorb the best sides of each other, strengthen your own weaknesses, and also continuously work on yourself to take a place in a changing world.

Keywords: lexicology of the Russian-Chinese translation dictionary; phraseology of the Russian-Chinese language; functional research.
$\mathrm{B}$ современную эпоху информатизации между странами возникает интенсивное взаимодействие и столкновение культурных ценностей. Изучение истории и культуры других стран, а также изучение их языка способствует усвоению культурных ценностей.

На формирование традиций, исторических и культурных ценностей оказывают роль такие факторы, как географическая среда, пищевые привычки, религиозные убеждения и т.д. В некоторых странах играют роль тотемные животные, что также может быть выражено в национальном языке. Жизненный опыт и бытовые знания накапливались и находили отражение в народных песнях, поговорках, мифах, сказках и др. средствах традиционной nреподаватель, Хэйхэский университет (Heihe University) ssf0246@163.com

Аннотация: Статья посвящена отражению важности изучения фразеологических единиц России и Китая. Актуальность работы обусловлена важностью установления межкультурного взаимодействия, а также стремления понять носителя другого языка. Главной задачей исследования является попытка систематизации сведений о составлении единого словаря. Автор предлагает создать русско-китайский словарь фразеологических единиц, с помощью которого можно было бы легче понимать культурные различия между странами. В конце работы автор приходит к выводу, что изучение фразеологических выражений двух стран позволяет понять разницу между двумя культурами, впитать в себя лучшие стороны друг друга, укрепить собственные слабости, а также непрерывно работать над собой, чтобы занять место в изменяющемся мире.

Ключевые слова: лексикология русско-китайского переводческого словаря; фразеология русско-китайского языка; функциональное исследование.

народной культуры.

«Русская фразеология складывалась в течение многих веков. Особенностью фразеологических единиц русского языка является краткое и точное выражение мыслей и концепций, обладающих национальным колоритом» [3, c. 68]. Именно фразеологические единицы играют значительную роль в изучении истории, культуры и эмоционального колорита каждой страны.

Кроме того, с помощью идиома или поговорки, сопоставляющей культурные различия и эмоциональные стремления русского и китайского языков, мы можем выявить культурные различия в обоих языках, чтобы избежать некоторых неловких сцен и недоразумений в общении.

1 Исследование выполнено в рамках научно-исследовательского проекта по философии и социологии провинции Хэйлунцзян «Функциональное исследование фразеологии русского (русско-китайского) языка в контексте построения лексикологии русско-китайского переводческого словаря» (2018), (18YYЕ698). 


\section{Функциональное исследование Фразеологических еАинич русского и китайского языков}

Процесс глобализации ускоряется, что позволяет всем народам мира взаимодействовать и делиться ресурсами с помощью таких средств коммуникации, как социальные сети. Многие люди учатся и стремятся содействовать обмену и интеграции культур между странами.

Обмены и сотрудничество между Россией и Китаем необходимы, торговые обмены между нашими странами не прерывались. Поэтому для китайцев обучение русскому языку также имеет решающее значение, поскольку, только изучая русский язык можно общаться с русским народом, вести переговоры о сотрудничестве с другими сторонами, а также повышать свои знания и опыт. В то же время, можно развивать дружбу с российским народом, изучать его передовую науку и технику, усиливать свои слабые стороны, понимать его образ жизни и быт, избегать в последующих обменах межкультурных недоразумений, которые не содействуют дружбе народов двух стран. Кроме того, в последние годы ряд специалистов проводят исследования в области русского и китайского языков, уделяя пристальное внимание углубленному сравнительному анализу китайских идиом. Некоторые данные свидетельствуют о том, что фразеологизмы про животных вносят значительный вклад в изучение традиционной культуры.

В современном высокоразвитом научно-техническом мире есть много технологий и материалов, которые могут помочь ученым в изучении русско-китайского языка, например: переводчик русско-китайского или китайского словаря и соответствующая теория перевода. «В контексте глобализации деятельность по письменному переводу рассматривается как творческое направление, охватывающее как языковые, так и культурные аспекты, требующие не только преобразования двух языков, но и, что более важно, содействия обмену между двумя культурами. Фразеология обогащает национальный язык и культуру, воплощает в себе особенности национальной географической среды, гуманистической истории, психологических факторов и языкового самовыражения» [5, с. 187].

Многие российские ученые и эксперты в течение многих лет изучали грамматику и семантику русского языка. Знаменитые лингвисты В.В. Виноградов и В.В. Телия посвятили свои исследования исследованию фразеологическим единицам. В частности, В.Н. Телия посвятила свои исследования лингвокультурологическим особенностям русского языка: «Фразеология в контексте культуры» (М., 1999), «Культурные слои во фразеологизмах и в дискурсивных практиках» (М., 2004) и др. В ее монографиях всесторонне описывается методика изучения русского языка, особенности употребления фразеологических единиц, значение идиом в контексте культурных ценностей.

Китайские ученые лишь недавно стали посвящать свои исследования вопросу изучения идиоматических единиц. Исследованию русско-китайских переводов также посвящено небольшое число работ.

Таким образом, необходимо изучить функцию русского и китайского перевода, а также необходимо создать исследования, позволяющие людям учиться и понимать знания, содействующие дальнейшему дружественному обмену между Китаем и Россией.

Китайские и русские фразеологизмы необходимо использовать для того, чтобы оба народа могли лучше общаться в условиях глобализации, а также делиться своими знаниями и пониманием вещей для создания гармоничной и инклюзивной международной обстановки.

Значение и развитие функшионального
исследования фразеологии русско-китайского
языка в контексте построения русско-китайского
словаря

С развитием современных технологий появилось много электронных пособий, благоприятствующих изучению русского языка. Однако, необходимы специальные материалы (переводчики и разговорники), чтобы люди могли применять свои знания в общении и в учебе.

Более того, несмотря на то, что Китай и Россия являются соседями, они обладают низким уровнем знаний культурных различий. Отметим, что на границе между двумя странами часто имеют место некоторые смехотворные недоразумения по причине того, что люди часто не понимают друг друга.

Для лучшего понимания культуры другой страны нужны специальные книги, написанные по-русски и покитайски. Для развития экономических отношений между странами необходимо владеть двумя языками. Поэтому, мы считаем, что изучение языка должно проходить в рамках изучения двух языков, чтобы сравнивать языковую структуру, грамматические особенности, лексические и семантические характеристики языковых единиц. Эти книги должны быть направлены на помощь ученым, начинающим изучать русский или китайский язык с целью понимания культурной и языковой специфики двух стран, а также обмена и интеграции культур.

Фразеологические единицы представляют собой устойчивые выражения с особенностями местного го- 
вора, поговорки из жизни, отражающие значительную часть традиционной культуры и языка. Фразеология является ключом к пониманию языка.

«Русские и китайские фразеологизмы очень различны по структуре, риторике и значению. Очень сложно найти полностью совпадающие по значению, стилистической окраске и культурному смыслу идиомы в изучаемых языках» [1, с. 34].

Таким образом, на фоне формирования русско-китайского переводческого словаря проводится сопоставление и анализ русского и китайского языков, выявляется сходство в понимании межкультурных вопросов, требующих внимания, что имеет практическое значение для русского и китайского перевода. Только детальные исследования и анализ русско-китайского языка позволят ученым лучше понять историю и культуру двух стран, их межнациональные особенности, обычаи и национальные чувства.

Увеличение количества исследований русско-китайского языка также является ответом на призыв процесса глобализации: только страны мира, понимающие друг друга и охватывающие географические и культурные различия, могут добиться взаимного уважения обычаев и религиозных верований друг друга. Это может способствовать дружественным, гармоничным отношениям между странами мира, а также создать прекрасное будущее, чтобы внести вклад в социальный прогресс человечества.

Только с точки зрения развития мировой лингвистики, русский и китайский фразеологизмы как особый языковой компонент двух стран имеют относительно стабильную языковую структуру, а также отражают чувства предков. Таким образом, исследование функции русского и китайского идиома на практике является всесторонним систематическим анализом и изучением традиционной культуры и национального обычая России и Китая, чтобы в максимальной степени помочь людям понять суть обоих языков. Кроме того, с точки зрения исторических и археологических исследований, русский и китайский фразеологический язык является зеркалом истории и культуры Китая и России, отражая идеологию, местные обычаи, политическую и экономическую систему различных народов в определенный период времени. «Фразеология содержит культурную самобытность и культурную информацию народа, которая тесно связана с культурными традициями и неразрывно связана с ними» $[2$, с. 45].

В процессе глобализации изучение русско-китайского языка может помочь людям повысить свои культурные навыки, понять мировоззрение, ценности и отноше- ние к окружающим проблемам народов Китая и России, углубить интеллектуальный обмен и дружбу между народами двух стран, содействовать торговому сотрудничеству и культурной интеграции между народами, усилить свои собственные уязвимые места.

Наконец, с точки зрения перевода, «язык каждого народа тесно связан с его культурой, и различные формы выражения языка отражают различия в национальной культуре. Перевод - это не только процесс трансформации двух языков, но и процесс межнационального культурного обмена. Переводчик должен не только владеть двумя языками, но и понимать культуру, которая стоит за этими языками, и на этой основе гибко применять переводческие навыки» [4, с. 200].

Русско-китайский диалект часто трудно перевести, так как он может смешиваться с местными диалектами, а это значительно затрудняет перевод. Поскольку местные диалекты не очень хорошо переводятся ни на китайский, ни на русский язык, чтобы перевести контекст и значение выражений, необходимо четко понять происхождение и историю появления фразеологизма. Только так можно отразить эмоции и значение идиомы, необходимые для понимания контекста. Только при условии правильного перевода идиом и иных выражений можно корректно использовать межнациональное общение.

Поэтому, несмотря на то, что в настоящее время появилось много средств для перевода на русский язык и китайский язык, исследование функции русского языка и китайского языка по-прежнему занимает большое значение.

Географическое расположение стран служит ориентиром, способствующим наладить направление обучения для российских и китайских начинающих лингвистов, способных впоследствии внести существенный вклад в развитие языка и его наследование.

\section{Зак^ючение}

Благодаря стремительному развитию высоких технологий, обновлению и замене ряда электронных продуктов, таких как мобильные телефоны и компьютеры, людям стало проще ориентироваться в изучении новых языков. Мы выяснили, что на данный момент нет комплексного исследования, посвященного изучению русского и китайского языков, в котором бы были отражены культурные различия двух стран.

Проведение исследований в этой области не только позволит глубже понять суть культурных различий других народов, но также поможет им лучше понять друг друга в процессе общения и тем самым наладить хоро- 
шее взаимодействие. С годами установления отношений между Китаем и Россией поддерживается дружественный обмен, поэтому изучение фразеологических выражений двух стран позволяет понять разницу между двумя культурами, впитать в себя лучшие стороны друг друга, укрепить собственные слабости, а также непрерывно работать над собой, чтобы занять место в изменяющемся мире.

\section{ЛИТЕРАТУРА}

1. Е. Сянжун Контрастность и перевод фразеологии русско-китайского языка. - Пекин: Пекинский педагогический университет, 2008. - С. 34.

2. Ли Дяньфан, Ван Цзяоцзяо. Общие вопросы и контрмеры в переводе фразеологии русско-китайского языка // Педагогический форум. - 2012. - № 4. - С. 45.

3. У. Диндин Понятие фразеологии русского языка: Сибирское исследование, 2016. - С. 68.

4. Фу Лияо. Изучение культурных различий в переводе на русский и китайский языки // Китайские и иностранные предприниматели. - 2019. - № 2. - С. 200.

5. Фэн Вэйцин. Использование в русском и китайском переводе // Культурный журнал. - 2015. - № 09. - С. 187.

\section{○ Сун Шуфэн (ssf0246@163.com).}

Журнал «Современная наука: актуальные проблемы теории и практики»

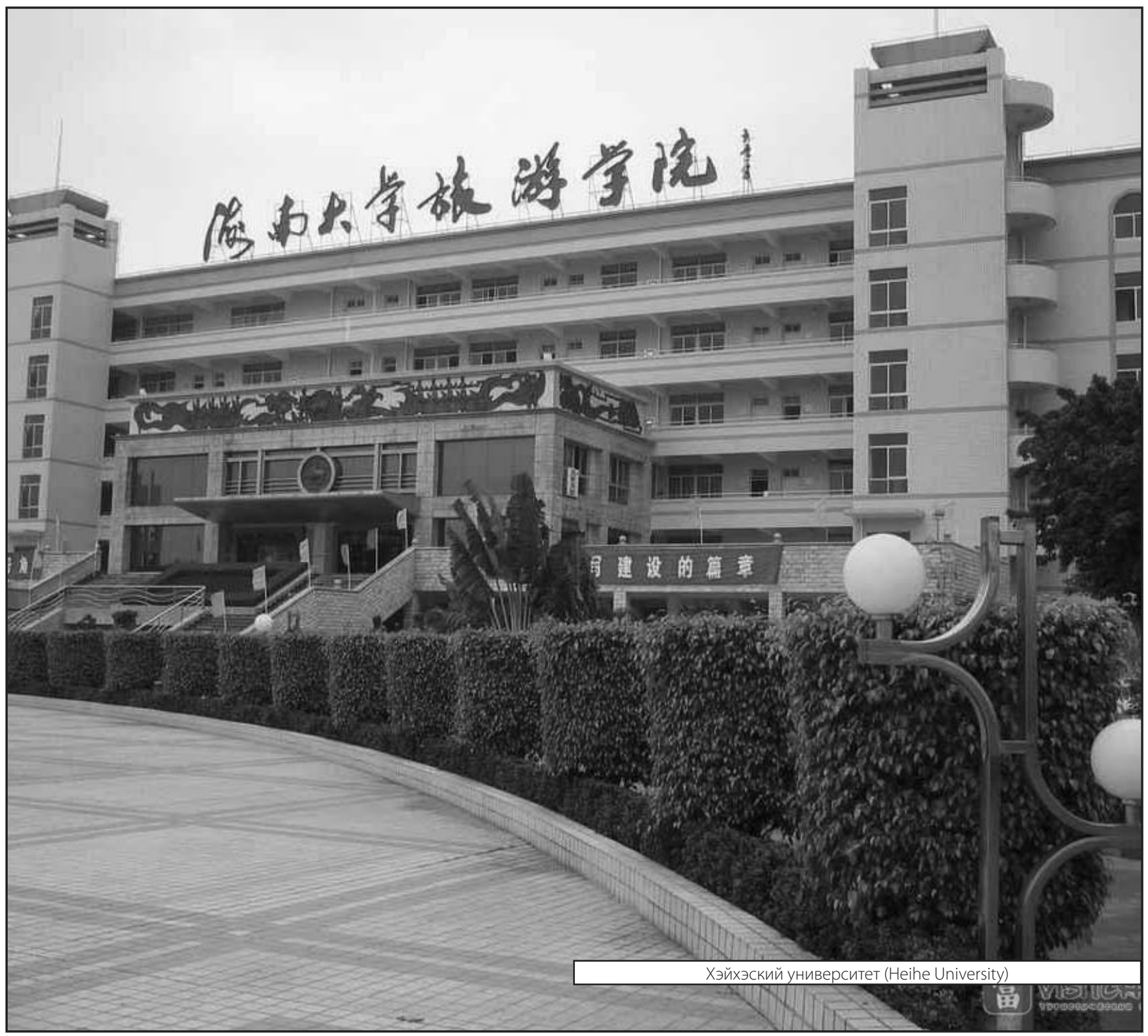

